\title{
SAGU (TAWARO) DAN KEHIDUPAN ETNIK TOLAKI DI SULAWESI TENGGARA
}

\author{
Basrin Melamba \\ Jurusan Sejarah, Fakultas Ilmu Budaya, Univiversitas Halu Oleo, Kendari \\ melambabasrin@yahoo.com.
}

\begin{abstract}
Sago is closely related to ethnic Tolaki life, because it has historical value for Tolaki. Sago have been known by Tolaki people since the 7th century and developed in the 15th century to the present. Sago has a very vital position. Sago as a symbol of wealth as a measure of economic (hapohapo), food reserves, food and other business sources. In the past, sago was also an inheritance (hapo-hapo tiari), and a symbol of prosperity. Sago has a value of philosophy in the form of the social value of family or kinship, unity and integrity values and religious values. Ecologically, there is every residential land of sago (epe) which serves to hold and fertilize the soil, used to make the well as it can save water, the sago ecosystem live in various habitats in the form of fish and plants that can be utilized. Sago ecosystem can provide many kinds of fish life. Thus, sago is one important element of people's lives in Tolaki.
\end{abstract}

Keyword: Sago, history, Tolaki

\section{ABSTRAK}

Sagu erat kaitannya dengan kehidupan etnik Tolaki, karena sagu memiliki nilai sejarah bagi Tolaki. Sagu telah dikenal masyarakat Tolaki sejak abad ke-7 dan berkembang pada abad ke- 15 hingga masa kini. Sagu memiliki kedudukan yang sangat vital. Sagu sebagai simbol ekonomi Tolaki sebagai ukuran kekayaan (hapo-hapo), cadangan pangan, sumber makan dan usaha lainnya. Pada masa lalu, sagu juga merupakan harta warisan (hapo-hapo tiari), dan simbol kesejahteran. Sagu memiliki nilai filosofi berupa nilai sosial kekeluargaan atau kekerabatan, nilai persatuan dan kesatuan dan nilai religius. Secara ekologi, setiap pemukiman Tolaki terdapat lahan sagu (epe) yang berfungsi untuk menahan dan menyuburkan tanah, dimanfaatkan untuk membuat sumur karena dapat menyimpan air, pada ekosistem sagu hidup berbagai habitat berupa ikan dan tumbuhan yang dapat dimanfaatkan. ekosistem sagu dapat menyediakan kehidupan berbagai jenis ikan. Dengan demikian, sagu merupakan salah satu elemen penting dalam kehidupan masyarakat Tolaki.

Kata Kunci: Sagu, Sejarah, dan Tolaki

\section{PENDAHULUAN}

Sagu atau tanaman sagu dalam kehidupan masyarakat Tolaki, merupakan suatu tanaman yang cukup penting. Beberapa indikator terkait dengan pernyataan di atas adalah, pertama, bahwa tanaman sagu merupakan suatu tanaman yang menjadi sumber makanan pokok bagi masyarakat etnik Tolaki. Kedua, pada masa lalu masyarakat Tolaki memperkembangkan teknologi tepat guna pengolahan kayu, bagian luar batang sagu (kulit luar pohon sagu) banyak digunakan untuk ramuan rumah, terutama dinding dan gelagar rumah bertiang yang banyak dijumpai di desa-desa pertanian masyarakat Tolaki. Ketiga, daun sagu tidak jarang digunakan sebagai atap rumah yang dikenal dengan sebutan atap rumbia. Keempat, daun sagu digunakan pula sebagai anyaman sebagai wadah untuk menyimpan barang atau bendabenda tertentu, terutama yang berkaitan dengan hasil ladang atau kebun, dan atau digunakan sebagai tempat perbekalan oleh para petani yang biasanya men- 
cari madu alam di daerah-daerah pedalaman daratan Kendari, Konawe, dan daerah Kolaka. Kelima, keberadaan pohon sagu di suatu areal tertentu mengindikasikan bahwa di sekitar daerah tersebut terdapat sumber air yang juga kaya dengan berbagai komunitas air tawar sebagai sumber kehidupan manusia.

Sagu merupakan tanaman yang dikenal di Nusantara, serta tumbuh di daerah seperti Papua, Maluku, dan Sulawesi. Di Sulawesi tanaman ini terdapat di Sulawesi Utara, Sulawesi Tengah dan Sulawesi Timur/Tenggara. Di wilayah Sulawesi Tenggara (Sultra) sagu tumbuh di bagian daratan terdapat di Kabupaten Konawe, Konawe Selatan, Konawe Utara, Kolaka, Kolaka Utara, Kolaka Timur, dan Bombana. (Dinas Pertanian dan Holtikultura Provinsi Sultra, 2010). Kabupaten ini pada masa lalu merupakan basis kerajaan tradisional Konawe dan Mekongga.

Daerah tersebut di atas merupakan tempat bermukimnya masyarakat Tolaki. Etnik Tolaki terdiri dua sub etnis yaitu: Tolaki Konawe di Konawe dan Tolaki Mekongga di Kolaka. (Kruijt, 1922, Tarimana, 1993, dan Melamba, 2012). Keduanya pada masa lalu mendiami dan memiliki kerajaan yaitu: kerajaan Konawe (Laiwui), dan kerajaan Mekongga. Dalam aktivitas mereka kehadiran $p u^{\prime} u$ ndawaro (pohon sagu) sangat berarti karena memiliki nilai dan makna ditinjau dari berbagai sudut pandang orang Tolaki. Artinya sagu memiliki nilai guna instriktik dan entristik. Siapa yang menyangka ternyata sagu (tawaro) bagi etnis Tolaki memiliki nilai yang sangat berguna bagi kehidupannya. Sagu merupakan jenis tumbuhan yang tidak lepas dari kehidupan orang Tolaki. Hampir semua bagian dari pohon sagu tersebut khususnya yang telah siap panen dapat dimanfaatkan untuk kebutuhan sehari- hari. Laporan perjalanan para etnografi dan pejabat zaman pemerintah Hindia Belanda menjelaskan mengenai eksistensi sagu (sagopalm/sagopalmenwal) di Sulawesi Tenggara (Elbert, 1911:253, Cruijt, 1921, Andriani, 1922, Fontjine, 1948). Sagu dikomsumsi oleh penduduk Tolaki sebagai makanan pokok (kinaa mbuu) bagi masyarakat Tolaki. Tanaman ini banyak tumbuh di rawa-rawa, dan dijadikan sebagai bahan baku pada rumah tradisional (Kruijt, 1922, Klif, 1929, Baden, 1925, Elbert, 1911:253).

Dalam karya Tarimana berjudul "Kebudayaan Tolaki" belum menjelaskan mengenai sagu kaitannya dengan kehidupan orang Tolaki. Ia hanya menjelaskan pranata Kalo (rotan dipilin tiga) kaitannya dengan kehidupan orang Tolaki. Kalo bagi masyarakat Tolaki memiliki fungsi, nilai, simbol, lambang, dan makna bagi masyarakat pendukungnya. Pentingnya kalo juga sama halnya dengan pohon sagu $\mathrm{pu}^{\prime} u$ ndawaro bagi orang Tolaki.

Pada tahun 2003, peneliti Jepang bekerjasama dengan perguruan tinggi Universitas Halu Oleo melaksanakan penelitian mengenai persaguan di Sulawesi Tenggara yang dipelopori oleh Dr. Yulius J. Pasolon, M. Agric. Ada beberapa aspek yang mereka teliti diantaranya, mengenai kandungan gizi dalam sagu, pemanfaatan sagu, budidaya, dan pengembangan sagu di Sulawesi Tenggara. Tetapi masalah sejarah dan sosial budaya dalam kaitannya kehidupan orang Tolaki luput dari penelitian mereka.

\section{METODE PENELITIAN}

Berdasarkan prosedur (tata kerja) metode sejarah, maka dalam penelitian ini ditempuh tahapan-tahapan sebagai berikut: Heuristik (Pengumpulan sumber) peneliti berusaha untuk mendapat- 
kan dan menghimpun sumber yang berkaitan dengan sejarah, sosial, budaya, dan ekonomi sagu. Dalam kegiatan ini, pengumpulan data dilakukan dengan langkah sebagai berikut: (1) Penelitian kepustakaan (library research) yaitu mengkaji beberapa arsip dan dokumen, buku, majalah asing (Belanda, Jerman), disertasi, makalah, skripsi, serta laporan hasil penelitian yang ada relevansinya dengan judul dan masalah dalam penelitian ini; (2) Penelitian lapangan (field research), yaitu mengadakan penelitian secara langsung dilokasi penelitian guna menghimpun data atau informasi yang berkaitan erat dengan topik. Selain pendekatan sejarah, penelitian ini menggabungkan dengan penelitian etnografi dari Spreadley (1995) Penelitian ini dilaksanakan pada masyarakat Tolaki yang mendiami Kabupaten Konawe, Konawe Selatan, Konawe Utara, dan Kolaka Timur, Provinsi Sulawesi Tenggara.

\section{HASIL DAN PEMBAHASAN}

\section{Melacak Sejarah Sagu di Tanah Tolaki}

Istilah sagu (Sago: Bahasa Inggris) berasal dan bahasa Jawa yang artinya tepung yang terkandung dalam empulur (Flach,1997). Tanaman sagu asli bernama Metroxylon sagu Rottb. Nama metroxilon berasal dari bahasa Yunani yeng terdiri dari dua kata yaitu Metra yang berarti batang atau empulur dan xylon yang berarti xilem (Flach, 1977 dalam Heryanto dan Panglili, 1992). Dari marga metroxylon hanya sepsis sagu yang tergolong hepaxanpthic (hanya berbuah satu kali lalu mati) dan sobohiferous (beranak=tiller atau sucers). Tanaman sagu termasuk famili Palmac Jusseu, subfamily calamoideae Griffith, kelompok calameae Drude, sub kelompok metroxylinae Blume dan marga (genus) Metroxylon Rottboell.

Dalam bahasa Indonesia pohon sagu asli disebut sagu, namun di berbagai daerah mempunyai nama daerah yang berbeda-beda (Haryanto dan Pangloli, 1992) seperti : Rumbia Minangkabau; Bak Meurauya atau bak sage di Aceh, Meniusatau rumbieu di Gayo, Rumbia atau baruhur di Batak, Saku di Nias; Kirai di Jawa Barat; Bulung, Kresula, ambulung, bulu, rembulung, atau resula di Jawa di Sangir Talud; Rambiam atau rabi di Kepualauan Arun, er di Kepulauan Kai, bai atau bonfia di kepulauan seram, dan huda di Ternate. Tumba di gorontalo, puntaworo di Toli-Toli, Tabaro di Luwu, dan tana Toraja, Tawaro di Kendari; Tobaro di pulau Wangi-Wangi; di Papua namanya papeda. Di Papua New Guinea, yang dikenal sebagai asal usul sagu terdapat nama lokal, namun umum dipakai adalah saksak. Di Malaysia sagu di beri nama rumbia atau balau di Serawak. Di Philipina sagu disebut lumbia; Thagubin di Burma, sa kuu di Kamboja, dan sa khu di Thailand. Di Perancis sagu disebut sagutier dan di Jerman disebut sagopalme. Sagu dalam bahasa Inggris disebut True sago Palm (Flach, 1997). Menurut Pasolon (2006:215) bahwa terdapat lima jenis atau spesis yang termasuk di dalam kelompok sagu asli Menoxylon sp sebagai penghasil tepung sagu yaitu: 1. Metnoxylon sagus rottboell, 2. Metroxylon rumphii martinus, 3. Metroxylon syvester martinus, 4. Metroxylon longispium martinus, dan 5. Metroxylon micracantum. Secara umum dalam taksonomi masyarakat dusun sagu (kampong penghasil sagu), sagu dikelompokan dalam dua kelompok besar yaitu: sagu berduri dan sagu tidak berduri. Sagu tidak berduri: Runggu Manu (Metroxylon sagus rottbeol), rui (Metroxylon micracantum). Untuk Sagu 
berduri terdiri sagu manu (Metroxylon Rumphii Martinus) dan rui (Metroxylon micracantum martinus).

Tepung sagu merupakan salah satu sumber pangan tertua dan termasuk komoditas pangan yang pertama kali memasuki perdagangan dunia barat pada abad ke-18 (Rumphius, 1759 dalam Flach, 1977). Tepung dalam empelur sebagai sumber makanan cadangan inilah yang dipanen manusia khususnya di Asia tenggara sebagai sumber makanan sehari-hari sebelum ada beras. (Pasolon, 2006:215). Tumbuhan sagu merupakan tanaman yang cukup tua dan dikenal di beberapa etnik di Nusantara. Pohon sagu merupakan tanaman yang banyak tumbuh di Indonesia dan Malaysia. Di beberapa negara seperti Filipina, dan Thailand sagu sudah mulai di budidayakan dan bahkan di Jepang diteliti untuk dijadikan bahan makanan tambahan. Sagu diduga berasal dari Maluku dan Irian. Hingga saat ini belum ada data yang pasti yang mengungkapkan kapan awal mula sagu ini dikenal. Di wilayah Indonesia Bagian Timur, sagu sejak lama dipergunakan sebagai makanan pokok oleh sebagian penduduknya, terutama di Maluku, Irian Jaya, dan Sulawesi.

Hasil-hasil penelitian terdahulu menunjukan bahwa keragaman genetik sagu terdapat New Genia (Papua). Dari hasil penelusuran sumber genetik tersebut diketahui bahwa sagu dari New Genia (Papua) tersebut kemudian menyebar ke Ambon, Seram, Halmahera, Sulawesi, Kalimantan, Mindanao, Sumatera dan Thailand. Dari hasil peneluusuran genetik tersebut diketahui bahwa semakin menjauh dari pusat genetic sagu atau asal usulnya (the center and the origin of sagu yaitu New Genia) keragaman genetik sagu semakin berkurang.(Rianse dan Pasolon, 2013: 1).

Sagu menurut sejarah orang Tolaki dibudidayakan sekitar abad ke-7 yang tinggal di sekitar sungai SourereNapooha, Mowewe Uluiwoi, Kerajaan Mekongga di Kolaka, yang kembali dari perantauan di Pulau Maluku membawa tanaman sagu. Selanjutnya dikembangkan oleh warga sebagai bahan makanan pokok dan tambahan. Selain itu rumah tradisional pada zaman kerajaan Konawe dan Mekongga menggunakan bahan dari pohon sagu baik berupa atap (o'ato) maupun untuk diding (orini). Laporan Vosmaer menjelaskan bahwa di kerajaan Mekongga berkembang pertanian dimana lahan pertanian ditanami dengan tanaman buah-buahan, padi, dan sagu. (1839: 13). Sumber tradisi lisan (oral tradition) bahwa persebaran tanaman sagu di tanah Tolaki berasal dari daerah Maluku dibawa oleh seorang bernama Onggabo yang bergelar Lolamoa Sangia Lawuta kemudian menjadi mokole Konawe pada sekitar abad ke-15.(Melamba, 2013: 114). Sejak saat itu raja dan masyarakat Tolaki menggalakan penanaman sagu (mombaho tawaro) pada areal epe. Untuk wilayah kerajaan Mekongga di Kolaka, wilayah persebaran sagu terutama Towua, Wundulako, Pomalaa, Rate-rate, Tirawuta, dan Lambadia. Sagu bagi masyarakat Tolaki memiliki makna, dan arti, kegunaan berkaitan dengan kehidupan ekonomi, adat, falsafah, kepercayaan, dan teknologi. Kehidupan orang Tolaki dengan sagu terkait dengan falsafah atau pandangan hidup, memiliki arti bagi lingkungan ekologi, berkaitan dengan makanan, peralatan, dan simbol adat. Seperti tanaman padi pada masyarakat Tolaki terdapat juga mitologi mengenai sagu berupa cerita dalam bentuk o'nango.

Periode 1815 dan 1885 terjadi musim paceklik dan wabah penyakit yang epidemis melanda kerajaan Mekongga, dan Konawe. Salah satunya wabah penyakit molude-lude. (Gwowelous, 1934; dalam Melamba, 2011:75). Hal ini 
diakibatkan oleh hujan abu "usa awu" akibat meletusnya gunung Tambora dan Krakatau. Padi ladang mengalami gagal panen menyebabkan kebutuhan akan beras berkurang. Salah satunya sumber pangan bagi penduduk hanya mengandalkan makanan tepung sagu (tawaro).

Berkenaan sejarah kuliner, sagu pada masa kerajaan Konawe selain dijadikan sebagai bahan makanan pokok bagi penduduk. Para pemimpinan etnik Tolaki dan Moronene juga mengkomsumsi tepung sagu (sinonggi, Tol). (Jong, 2010:101). Sagu juga berfungsi sebagai salah satu benda adat dalam peminangan (moawo niwule, momboko ndetoro obite) dalam proses perkawinan. Pada masa pemerintahan Mokole Tebawo gelar Sangia Inato, memerintahkan kepada pejabat Tusawuta bernama Latuo yang bertanggung jawab bidang pertanian. Untuk menggalakan segenap penduduk di wilayah Kerajaan Konawe agar membudidayakan sagu mombaho tawaro di setiap kampung pada lokasi o'epe dan arano (rawa). Epe adalah tanah atau rawa yang ditanami pohon sagu. Tanah yang dimiliki perseorangan dengan hak epe. Hak epe hanya dimiliki golongan bangsawan anakia dan dapat diwariskan kepada turunannya. (Tawulo, 1986; Lakebo, 1986/1987:62;). O'epe berlaku sama dengan tanah adat. Setiap rumpun sagu ada pemiliknya, luasnya hak seorang tergantung pada luas atau tumbuhnya sagu, karena sagu makin lama areal tumbuhan dan berkembang semakin luas. (Tamburaka, 1985/1986:44,45). Menurut laporan Vosmaer yang menjelaskan bahwa tanaman sagu banyak terdapat di daerah ini, hal ini disebabkan oleh karena bagi sebagian penduduk, sagu merupakan makanan pokok bagi penduduk pribumi. (1839:10).

Dalam menanam dan memanen sagu masyarakat Tolaki memiliki aturan sara mombopaho yang disebut o'wua yaitu aturan khusus bercocok tanam pada umumnya termasuk sagu (Tarimana, 1985:70; Su'ud, 2006). Pada masa lalu jika pohon sagu telah tumbuh pada daerah rawa, maka orang lain tidak boleh menanam sagu disekitarnya. (Tamburaka, 1985/1986:45;Lakebo,1 986/1987). Pada masa itu masyarakat Tolaki berkenaan dengan integrasi sistem ekonomi, dari sekian banyak jenis barang produksi maka sesungguhnya hanya ada tiga jenis diantaranya yang paling berperan dalam sistem ekonomi keluarga, yakni: ternak (kerbau), sagu, dan barang-barang pusaka. Binatang ternak mewakili identitas ayah, barangbarang pusaka mewakili ibu, dan rumpun sagu adalah identitas anak. (Tarimana, 1993:95).

Sagu di kerajaan Mekongga Kolaka dijelaskan bahwa selain itu hidup penduduk di semenanjung sebelah Tenggara yang berpenghasilan dari tepung sagu (tawaro) yang diolah dari pohon sagu. (Elbert, 1911:251). Pada masa pemerintahan Bokeo Teporambe mulai digalakan penanaman sagu di daerah Wundulako, Manggolo, Tongauna, Mambulu, Rate-Rate, Loea, Mowewe, dan Watubangga. Pada umumnya pohon sagu tumbuh secara berkelompok dan membentuk sampai menjadi kawasan yang luas (seperti hutan). Lebih lanjut dijelaskan bahwa pohon sagu yang terbesar ditemukan di daerah distrik Mambulu dan terutama di daerah pesisir Kolaka. (Elbert, 1911: 253).

Para pemimpin tobu (Pu'u tobu) pemerintah setingkat tobu (distrik) hingga tingkat o'napo atau kampung diwajibkan untuk menanam sagu. Sagu dijadikan sebagai bahan makanan bagi masyarakat Konawe dan Kolaka. Kebijakan ini menyebabkan di beberapa wilayah tobu di kerajaan Konawe terdapat beberapa areal pohon sagu yang sangat luas seperti $a^{\prime}$ epe Uepai, a'epe Asinua, a'epe Latoma, a'epe sampara, a'epe 
Bondoala, a'epe Lasolo, a'epe Meluhu, a'epe Lembo, a'epe Pamandati (Lambuya), dan sebagainya. Masingmasing epe ini dijaga dan dipelihara oleh masing-masing klen.

Bagi penduduk yang memiliki pohon sagu (tawaro), damar (dambara), enau (orema), dan jati (odati), tidak dikenakan pembayaran jika peruntukannya hanya sekedar untuk dipakai sendiri kecuali dalam jumlah besar. Dalam hal pemilikan dan pengambilan secara besar-besaran, maka yang bersangkutan diwajibkan membayar pajak atau iuran yang disebut osuke sebanyak 10 persen atau sepuluh bagian. Selain osuke ini, ada juga pembayaran (pemberian) secara sukarela peombu persembahan kepada raja (mokole) atau anakia (bangsawan) sebagai ucapan terima kasih atas perkenaan untuk memiliki atau mengambil terhadap penggunaan hak peserta. (Tawulo, dkk, 1990:55). Seserahan ini juga sebagai upaya menopang raja mokole dalam memerintah karena pandangan politik orang Tolaki bahwa rakyat sebagai posudo atau tumuboi anakia penopang penguasa, sebaliknya raja bertindak sebagai peokindoro ano to'ono ngapa (tempat meminta perlindungan dan pertolongan masyarakat). Pembayaran osuke ini dimaksudkan untuk pembiayaan kepentingan dan keperluan kesejahteraan masyarakat hukum adat, yang diurus oleh pembantu raja bidang pertanian yaitu Tusawuta bergelar Anakia Ndusawuta. (Yusuf, 1990:52).

Selain itu pemberian sesuatu jenis produksi seperti sagu kepada pemerintah kerajaan, dan kepada kaum kerabat dan tetangga lainnya. Didasarkan pada pandangan mereka bahwa hal ini merupakan syarat mutlak bagi kelangsungan usaha tani mereka agar produksi senantiasa melebihi, bernilai tambah, dan melimpah. Pandangan ini terkandung dalam ajaran-ajaran pokok mereka dalam mata pencaharian yang mereka sebut: o'wua, o'lawi dan o'sapa. (Tarimana, 1993: 70\&76). Selain itu merupakan manisfestasi dari proses tukar menukar hasil produksi masingmasing sebagai apa yang disebut mombekakaka'ako (saling menikmati makanan hasil produksi satu sama lain). Kenyataan tukar menukar ini merupakan salah satu bentuk dari perwujudan prinsip reciprocity (timbal balik) yang menggejala pada banyak masyarakat pedesaan di dunia.

Untuk mengambil hasil sagu tidak perlu izin kepada mokole (raja), tetapi cukup melalui penguasa wilayah tobu yang dipimpin oleh $P u^{\prime} u$ tobu, dan penguasa tingkat kampung (o'napo) dipimpin oleh To'ono motuo atau pembantu yang disebut Posudo (Su'ud, 2006). Menurut hukum adat, hak atas tanah areal sagu oepe sepenuhnya dikuasai oleh masyarakat tobu. Setiap masyarakat di dalam suatu tobu atau wilayah mempunyai hak membuka dan menguasai serta memiliki tanah (Lakebo, 1985/1986: 53-54). Raja (Mokole) memegang hak persekutuan atas tanah, bukan pemilik. Raja hanya mengatur dan menguasai pemukiman tanah dalam wilayahnya sehingga hak perseorangan tidak merugikan. (Lakebo, 1985/1986: 53-54). Menurut Controleur Taatgen dalam memorie van overgave van den onderafdeeling Kendari bahwa sagu juga ditanam dan semua hutan sagu mempunyai pemilik, pemungutan oleh bukan pemilik hanya dapat dilakukan dengan bagi hasil (kebanyakan seperti untuk pemiliknya).(1935:8-9)

Pada zaman pemerintahan Hindia Belanda di Konawe dan Kendari 1906, pemerintah Belanda tetap menghargai dan memberlakukan hukum adat diantaranya mengenai kepemilikan areal sagu O'epe. Areal tanaman sagu o'epe tetap dibiarkan tumbuh, bahkan kepemilikannya oleh klen-klen 
masyarakat hukum adat diakui. Menurut sumber bahwa periode ini produksi sagu di Kendari (Laiwui) dan Kolaka meningkat, hal ini dapat kita lihat meningkatnya ekspor keluar bagi kepentingan perdagangan termasuk di Kolaka. (Melamba, 2011:70). Berikut jumlah ekspor komoditi sagu di Kolaka mulai tahun 1926-1935.

Tabel 1. Jumlah Ekspor Sagu Tahun 19261935

\begin{tabular}{llll}
\hline No & Thn & $\begin{array}{l}\text { Jumlah } \\
(\mathbf{k g})\end{array}$ & $\begin{array}{l}\text { Nilai Uang } \\
\text { (f) }\end{array}$ \\
\hline 1. & 1926 & 53924 & $2.187,80$ \\
2. & 1927 & 23660 & 1.097 \\
3. & 1928 & 27140 & 1403,50 \\
4. & 1929 & 20880 & 1.029 \\
5. & 1930 & 27140 & 1403,5 \\
6. & 1931 & 27140 & $1.403,5$ \\
7. & 1932 & 2008 & 622 \\
8. & 1933 & 7090 & 245 \\
9. & 1934 & 11483 & 535 \\
10 & 1935 & 2109 & 240 \\
& Jumlah & 28053204 & 1.744 .316 \\
\hline
\end{tabular}

Sumber: Zlabbekoorn, 1935:51-52.

Di daerah Kolaka merupakan penghasil sagu dan diekspor keluar daerah diantaranya ke Makassar, Buton, Palopo, Bone, Pulau Boero, Tukang Besi dan beberapa daerah yang berada di sekitar kawasan teluk Bone. Adapun data produksi dan jumlah ekspor sagu dapat dilihat pada tabel diatas. Dalam laporan perjalanannya menyusuri pedalaman Kolaka, Johanes Elbert menyatakan bahwa di daerah ini banyak ditemukan pohon sagu, yang dibudidayakan oleh masyarakat To Mekongga serta dijadikan sebagai makanan pokok dan bahan ekspor, yang diolah secara tradisional (Elbert, 1911:258-259).

Daerah perdagangan sagu meliputi seluruh daratan Kendari dan Kolaka, kemudian diekspor keluar seperti ke Palopo, Makassar, Bone, Selayar, bahkan di kepulauan Buton (Toekang Besi Eilands) (Zlabbekoorn, 1926/1937; Arsip Daerah Sultra, 1946-1952). Periode ini juga di daerah Rumbia mengekspor sagu secara besar-besar ke Makassar dan Malaysia. Karena produksi sagu ini dikenal di dua wilayah ini yaitu Tolaki dan Moronene. Selain itu diekspor ke distrik Bantaeng Sulawesi Selatan, termasuk konsumsi untuk penduduk lokal. (Ghodhart, 1920: 171174; Jong, 2010: 101). Periode ini juga dilaporkan wilayah onderafdeeling Kendari sebagai penghasil beras yang diekspor keluar diantaranya Buton, dan Makassar. Harga beras di Kendari mencapai f.3.50 jika dibandingkan dengan harga beras di daerah Bone f.2,50. Padi menjadi produk ekspor yang paling menguntungkan dan penduduk memperhatikan ketersedian pangan. Penduduk tidak melihat adanya ancaman dalam penjualan beras karena mereka makan sagu (Taatgen, 1935: 8). Tetapi sisi lain makanan sagu pada saat itu menimbulkan penyakit beri-beri.

Periode tahun 1950-an kondisi keamanan di Kawedanan Kendari akibat gerakan DI/TII membuat penduduk mengalami kesulitan dalam memenuhi kebutuhan sehari-harinya terutama beras padi ladang. Sagu menjadi makanan alternatif karena sagu dapat diolah secara sembunyi-sembunyi, selain itu dapat diolah ditengah hutan sagu tanpa diketahui oleh musuh. Mengolah sagu dengan cepat tidak membutuhkan waktu lama, sangat mudah dan supel. Jika dibandingkan dengan kegiatan membuka ladang mondau untuk lahan pertanian padi. Kondisi saat itu sangat tidak memungkinkan untuk melaksanakan sistem pertanian berladang (mondau) karena alasan keamanan. Mondau membutuhkan waktu lama, dan bersifat terbuka. Sehingga sagu menjadi alternatif 
dan andalan penduduk setempat, dengan pertimbangan keamanan. Sistem pengolahan sagu yang dilaksanakan penduduk setempat lebih bernuansa moral ekonomi petani hanya untuk kebutuhan sehari-hari bukan orientasi pasar. Sejak tahun 1980-an sagu mulai diperjual belikan oleh penduduk setempat. Pada periode tahun 2000-an muncul pengusaha sagu dan memproduksi dan mengekspor sagu secara besar-besaran ke luar Sulawesi yaitu ke Surabaya.

Sebagai makanan tambahan selain beras, orang Tolaki juga menanam sagu (metroxilon sp). Sagu ditanam pada tanah-tanah berlumpur di pinggir sungai dan rawa. Proses pemeliharaannya sangat mudah. Tanaman baru diberi pagar perpohon untuk menghalangi gangguan babi. Setelah tumbuh dan mulai berbatang, tidak lagi diperlukan pagar tetapi cukuplah dibersihkan rumput di sekitar pohon (Tarimana, 1993: 83). Dalam sengketa adat mengenai areal tanaman sagu (Aepe), maupun tapal batas (mberano) kepemilikan areal tanah, kepemilikan areal tanaman sagu hingga berkaitan tiari (warisan). Maka untuk menyelesaikan sengketa tersebut digunakan cara mesaku (Su'ud, 2006). Berkenan dengan data areal pohon sagu kita menghadapi kendala yaitu instansi atau lembaga pemerintah tidak merasa memiliki sagu, data provinsi dan data Kabupaten dalam angka tidak memiliki data sagu, dan beberapa dinas (perkebunan, Pertanian), merasa tanaman sagu bukan kompetensi mereka (Bintoro, 2013:5).

Areal sagu di Sulawesi Tenggara yang pada tahun-tahun 1960-an diperkirakan mencapai sekitar 10.000 ha, pada saat sekarang ini areal itu berkurang dari waktu ke waktu seiring dengan pelaksanaan pembangunan sekitar 1.698 ha. Di Kabupaten Konawe misalnya, menurut data dari dinas pertanian setempat tinggal mencapai 898 ha, dan di Kabupaten Kolaka tinggal sekitar 800 ha (Konawe dalam Angka, 2011:124)

Berkenan dengan data areal pohon sagu kita menghadapi kendala yaitu instansi atau lembaga pemerintah tidak merasa memiliki sagu, data provinsi dan data Kabupaten dalam angka tidak memiliki data sagu, dan beberapa dinas (perkebunan, Pertanian), merasa tanaman sagu bukan kompetensi mereka.

Sekarang areal sagu yang luas masih dapat temui di pedesaan Kabupaten Konawe, Konawe Selatan, Konawe Utara, Kolaka, dan Kolaka Timur. Sagu belum dijadikan komoditi perdangangan, hal ini dilaporkan oleh Dinas Pertanian dan Holtikultural Kabupaten Kolaka Timur, hal ini dapat dilihat dari pengalokasian anggaran yang diberikan sangat kecil bahkan hamper tidak ada, begitu pula sisi luas pertanaman sagu yang ada saat ini hanya sekitar 700 Ha lebih, yang tersebar di beberapa Kecamatan di kabupaten Kolaka Timur (Anonim, 2013:2). Kondisi di Kolaka Timur sama yang dialami dengan Kabupatan lain yang ada di Sulawesi Tenggara.

Meskipun diakui luas areal sagu semakin berkurang hal ini disebabkan oleh, pertama, masyarakat sudah jarang membudidayakan sagu atau meremajakan. Kedua daerah o'epe sebagian sudah dialifungsikan sebagai lahan persawahan, pemukiman transmigrasi, areal perkebunan tebu, areal perkebunan kelapa sawit, dan untuk pemukiman. Ketiga, upaya pemerintah daerah melakukan pembakaran dan pemusnahan tanaman rakyat sagu di beberapa wilayah di Konawe, (Arsip BPAD, nomor:814). Keempat, kebakaran hutan sagu yang pernah melanda kawasan lalo epe, terutama pada musim kemarau, kelima, eksploitasi pengolahan sagu tid- 
ak diiringi dengan upaya budidaya, keenam, sektor pekerjaan mengolah sagu sumaku (menokok) bagi masyarakat Tolaki mulai ditinggalkan, lebih memilih menjadi buruh harian. Ketujuh, banyak pohon sagu yang sudah tua melewati masa panen hal ini disebabkan oleh pengolah sagu semakin terbatas. Dan kedelapan, pemilik penduduk asli telah banyak menjual tanah areal sagunya kepada penduduk pendatang dan pengusaha. Di pedesaan Sulawesi Tenggara pemukiman penduduk masih kita temui pada bagian samping atau di belakang rumah pemukimannya tumbuh pohon sagu.

Sagu sangat penting bagi kehidupan orang Tolaki karena pertama, pada masa lalu sebagai harta warisan (hapo-hapo tiari), simbol kesejahteran, kedua, simbol adat sebagai seserahan, ketiga, sebagai makanan pokok, keempat sagu terkait dengan falsafah hidup Tolaki, kelima, berkenaan bahan baku peralatan, keenam, berkaitan dengan pola ekologi, tumbuhan dan akar sagu menahan erosi, dan banjir serta tanah longsor karena sagu memiliki akar serabut. Selain itu pohon sagu berfungsi sebagai penyerap, menyimpan dan sebagai sumber air. Dan berbagai hal yang berkaitan dengan kehidupan orang Tolaki.

Sagu bagi masyarakat Tolaki memiliki nilai berkaitan dengan aspek kehidupan mereka diantaranya sebagai simbol adat, falsafah sebagai pandangan hidup, sebagai sumber kehidupan fungsi ekonomi, fungsi ekologi, makanan pokok, dan sumber bahan baku untuk alat bagi kehidupan Tolaki. Secara psikologi saya baru mengerti mengapa orang Tolaki jika diejek makan sinonggi menyebabkan tersinggung atau marah, hal ini dapat dipahami karena keterkaitan kehidupan Tolaki dengan sagu.

Mengapa sagu menarik diteliti dari aspek culture karena sagu memiliki nilai dan makna pada etnik Tolaki di Sultra. Komoditi sagu memiliki nilai ekonomi, nilai sosial, nilai historis, dan nilai ekologis atau lingkungan bagi etnik Tolaki. Secara historis, eksistensi tanaman sagu di wilayah daratan Kendari, Konawe, dan Kolaka belum banyak dikaji secara ilmiah. Namun demikian, pemanfaatan tanaman sagu oleh masyarakat Tolaki yang banyak mendiami beberapa daerah seperti disebutkan diatas.

\section{Pengolahan Sagu: Sebuah Transfor- masi}

Berbeda dengan sistem pengolahan padi di ladang yang penuh dengan upacara dan ritus, maka dalam sistem pengolahan sagu tidak diperlukan upacara kecuali pengucapan mantra-mantra pada saat untuk sumandu memanen. Tidak semua orang Tolaki mengkonsumsi sagu dan pandai menokok tetapi mereka juga mengkonsumsi nasi, pandai mengolah ladang padi (mondau) dan tekun mengikuti upacaraupacara berkenaan dengan pemujaan dewi padi. Tidak semua orang Tolaki menanam sagu, tetapi pada umumnya memelihara apa yang telah ada sebagai warisan nenek moyangnya (Tarimana, 1993: 83).

Ciri-ciri pohon yang sagu yang siap dipanen menurut masyarakat Tolaki adalah: (1) Pelepah daun menjadi lebih pendek; (2) Kuncup bunga mulai tampak dan pucuk pohon mendatar bila dibandingkan dengan pohon sagu yang lebih muda; (3) Batang sagu dilubangi kira-kira 1 meter di atas tanah, kemudian diambil empulurnya dan dikunyah serta diperas. Apabila air perasannya keruh berarti kandungan acinya sudah cukup dan pohon sagu siap dipanen. Proses pengolahan sagu 
yaitu : mowuwu (melubangi batang sagu untuk memeriksa apakah telah cukup mengandung tepung sagu), mondusa (mendirikan bangunan diatas tiang untuk memproses pemisahan tepung sagu dari ampasnya), mondue (menebang batang sagu), mowota (membelah-belah batang setelah dipotong-potong menurut keperluan), sumaku (memukulmukul bulir sampai menjadi serbuk), lumanda (menginjak-injak serbuk setelah diacampur dengan air untuk diendapkan), dan terakhir sumandu (endapan sagu yang masih basah dimasukkan kedalam basung). Keseluruhan proses pengolahan ini disebut sumaku (menokok) (Tarimana, 1993:83-84).

Berikut peralatan yang digunakan dalam proses pengolahan sagu secara tradisional yaitu: Suli (betel), alat ini terbuat dari kayu besi yang salah satu ujungnya diruncing hingga menyerupai linggis. Alat tersebut mempunyai panjang kurang lebih $25 \mathrm{~cm}$. Saku (alat untuk memukul bongkahan sagu menjadi butiran atau tokok). Alat ini terdiri dari dua bagian, yaitu mata saku dan tangge saku. Antara mata saku dan tangkainya selalu dipisahkan dan nanti pada saat akan dipakai baru dipasang. Bahannya terdiri dari kayu. Panjang tangkai $30 \mathrm{~cm}$, sedang matanya sekitar $29 \mathrm{~cm}$. Sandu (sendok), bahannya dari kayu ringan. Bentuknya seperti sendok nasi, mempunyai daun dan tangkai. Pajang keseluruhannya kurang lebih $20 \mathrm{~cm}$. Tambutambu (timba), daunnya terdiri dari pelopak sagu (kumba) yang dibentuk sebagai kerucut atau seperti topi yang runcing. Tangkainya dari bambu atau kayu kecil yang pajangnya kurang lebih 2 meter. Basu ndinggawu, bahannya terdiri dari pelopak sagu dan rotan. Tingginya $90 \mathrm{~cm}$, lebar (luas) penampang atasnya kurang lebih $35 \mathrm{~cm}$. Basung ini diberi tali dengan kulit kayu (rongo). Sanggobi, bahan dan bentuknya sama dengan basu ndinggawu, hanya ukurannya agak kecil dan tidak bertali. Isinya kurang lebih 15-30 liter sagu bersih. Landaka, bahannya terdiri dari rotan yang dibelah dan dianyam. Lubanglubang (selahnya) agak besar/luas. Di dalamnya dilapis dengan ijuk sebagai saringan. Tinusa, (panggung) (Mekuo, 1985:45).

Dalam mengolah sagu secara tradisional dengan menggunakan alat seperti: saku, suli, landaka, basu, lume, kawanggu, dasa-dasa dan kuwa. Pada perkembangan selanjutnya maka sejak tahun 1990-an beralih ke sistem pengolahan sagu secara modern dengan menggunakan alat diantaranya mesin parut (paru masina) untuk memarut, jaring untuk menyaring ampas sagu, karung untuk tempat memasukan tepung sagu, terpal menampung sementara hasil perahan tepung sagu, kain untuk menyaring tepung sagu, kampak untuk memotong tetapi diganti dengan menggunakan mesin potong sensor, dan linggis. Perubahan sistem pengolahan sagu dari tradisional ke modern disebabkan oleh diperkenalkannya mesin pengolah sagu (mesin parut) oleh pemerintah Provinsi Sultra melalui Dinas Sosial. Pengolahan secara modern memiliki kelebihan diantaranya hasil produksi lebih banyak, pemanfaatan waktu lebih efektif dan efesien jika dibandingkan dengan cara tradisional.

Pada masa lalu sistem kerja mengolah sagu secara bergotong royong samaturu, dengan membentuk kelompok pengolah sagu (to'ono sumaku) terdiri dari dua sampai empat orang dengan sistem bagi hasil. Sistem pembagian hasil produksi pengolahan sagu sekarang mengalami perubahan jika sebelumnya sistem pembagian 3 : 1 , yaitu 2 bagian untuk pemilik sagu, 1 bagian untuk pengolah sagu (jika jumlah keseluruhan 30 basu atau basung maka 20 basung untuk pemilik dan 10 basung untuk pengolah. Konsep bagi hasil 
sekarang berubah menganut sistem bagi hasil yang sama yaitu: 1: 1 atau lebih dikenal dengan konsep metia mengena atau metia hasele (sistem bagi hasil beimbang/bagi sama).

Potensi tanaman sagu yang ada di daerah Kabupaten Konawe, Konawe Selatan, Konawe Utara, Kolaka, dan Kolaka Timur sudah dikelola dengan baik, hal ini dapat dilihat dari banyaknya kelompok-kelompok kerja yang terdiri dari 6 kelompok. Jumlah empat kelompok pengolah sagu secara modern dan 2 kelompok pengolah sagu secara tradisional. Kelompok pengolah sagu secara modern dalam melakukan pengolahan sagu beranggotakan 3-6 orang. Untuk kelompok pengolah sagu secara tradisional melaksanakan pengolahan sagu dengan beranggotakan 2 sampai 3 orang.

Secara etnobotani sagu merupakan tumbuhan yang paling dikenal oleh masyarakat Tolaki karena tumbuh di lingkungan sekitar pemukiman dan areal perkebunan. Bahkan orang Tolaki kadang mudah marah jika disinggung melalui makanannya, 'saling ejek' makanannya sinonggi. Kasus ejek makanan pernah terjadi menyebabkan timbulnya perkelahian antar kelompok. pemicunya karena ejekan Tolaki makanannya sinongi. Ada anggapan orang Tolaki malas karena suka mosonggi. Tetapi ini sebenarnya hanya ejekan dari sekelompok orang bersifat etnosentris.

Hidup ditengah ekologi sagu cukup memudahkan, jika sekelompok orang melaksanakan kegiatan sumaku. Maka cukup membawa wadah, korek api (otinggu), dan garam (peanihi), tak perlu repot karena selesai menokok sagu dapat langsung mosolori (andonan empelur sagu siap saji), karena bahan untuk membuat sinonggi sangat mudah dan sudah tersedia tepung sagu (tawaro). Berbagai macam jenis ikan berada di lingkungan sekitar areal sagu, serta uwato (ulat sagu yang dapat dikomsumsi).

\section{Sagu dan Falsafah Hidup dan Makna Orang Tolaki}

Pandangan hidup atau falsafah orang Tolaki berkenaan dengan sagu dikaitkan dengan konsep perkawinan dalam bahasa Tolaki disebut merapu. Merapu berasal dari bahasa Tolaki "rapu" berarti rumpun, dan awalan me artinya melakukan. Term "rapu" diambil dari filosofi sagu jika tumbuh dan berkembang selalu merumpun (rapurapuno). Begitupun pandangan orang Tolaki dalam berkeluarga jika dikaitkan dengan sagu merupakan simbol kekerabatan. Sagu terdiri dari jenis laki-laki (langgai/otama), perempuan (otina/omore), dan anak sagu (ana ndawaro). Istilah rapu -rapuno artinya serumpun. Menurut Berthyn Lakebo (1986/1987), keluarga batih disebut rapu artinya rumpun. Seorang yang menikah disebut merapu artinya membentuk rumpun atau rumah tangga.

Ungkapan yang berbunyi 'monapa mbuundawaro' jika ditelaah secara mendalam, terdapat banyak aspek yang dapat dikemukakan terkait dengan ungkapan tersebut. Beberapa hal dimaksud, pertama bahwa kata 'monapa' dan 'ndawaro' merupakan dua kata dalam bahasa Tolaki yang selain telah beraspek masa lampau (arhkais) juga menginformasikan kepada kita bahwa di dalam bahasa Tolaki dikenal tingkatan bahasa (level speak). Dikatakan demikian karena dalam ungkapan sehari-hari, untuk melukiskan suatu keadaan yang sejuk atau dingin menggunakan istilah morini bukan monapa, sedangkan kata sagu dalam bahasa sehari-hari menggunakan kata tawaro dan bukan ndawaro. Kedua, bahwa pribahasa monapa mbuundawaro yang 
berarti sejuknya pohon sagu, menginformasikan kepada kita bahwa tanaman sagu dalam kehidupan masyarakat etnik Tolaki sangat esensial. Dikatakan demikian karena pada umumnya pepohonan terutama yang berdaun lebat dan rindang dapat menyejukkan lingkungan sekitarnya, namun tidak dijadikan sebagai simbol kesejukan dalam kebudayaan masyarakat Tolaki dimaksud.

Tanaman sagu dalam pandangan orang Tolaki sebagai simbol persatuan karena tumbuhan ini selalu bersatu merumpun (rapu), dalam aktivitas perkawinan khususnya acara pelamaran salah satu tumbuhan yang dibawah oleh sang pengantin laki-laki adalah dua rumpun pohon sagu (puu ndawaro) yang masih kecil untuk ditanam kelak. Jumlah dua melambangkan dua pasangan suami istri laki-laki dan perempuan. Sagu simbol kehidupan berumah tangga, selain sebagai bahan makanan juga simbol kesuburan. Kedua pohon sagu ditanam apabila kedua pohon sagu ini tumbuh dan berkembang, diharapkan keluarga baru ini dapat berkembang biak seperti sagu, dapat bersatu seperti sagu merapu artinya tidak hanya suami istri yang menyatukan cinta dan kemauan mereka. Tetapi bersatunya kedua rumpun keluarga, rumpun keluarga saling menyatu dan merumpun. Terdapat pesan orang tua kepada sang pengantin "ano eheki meohai, ano dului peohaino ari ine walino ronga ari ine sabeano" artinya hendaklah engkau suka menjalin kekerabatan, dapat menjalin hubungan dengan keluarga suami begitu sebaliknya mampu menjalin hubungan dengan keluarga istrinya.

Sagu sebagai warisan (tiari) atau hapo-hapo tiara (Su'ud, 2006: 45; Koodoh, 2011), juga sebagai benda yang digunakan untuk seserahan adat (Melamba, 2013). Mengapa menggunakan pohon sagu karena pada masa lalu seorang laki-laki atau pemuda jika ingin mempersunting seorang gadis, maka terlebih dahulu laki-laki tersebut harus berkerja dikebun orang tua perempuan calon mertua, dengan cara membuka ladang (mondau), menanam sagu (mombopaho tawaro i'lalo epe). Memiliki tanaman sagu yang luas merupakan kebanggaan tersendiri. Tanaman sagu yang luas secara ekonomi dalam pandangan orang Tolaki termasuk mapan, sekaligus dihargai dan dihormati dimata masyarakat. Ini biasanya dimiliki oleh masyarakat yang sejak dahulu memiliki rumpun sagu yang luas atau merupakan warisan dari leluhur.

Sagu berfungsi sebagai benda seserahan adat meminang (mondongo niwule) bagi masyarakat Tolaki. Sagu simbol kekayaan orang Tolaki, selain kerbau (kiniku/karambau), dan tanah (owuta). Filosofi sagu tumbuh dan beranak, tumbuh secara lurus (lumuu), dan bergerak maju, dapat tumbuh ditempat yang berair, tumbuhnya bergerak maju. Diharapkan keluarga dalam menjalankan bahtera rumah tangganya dianalogikan seperti sagu, beranak berkembang, berumpun, mampu menghadapi tantangan dalam kondisi apapun, bersifat tenang, dan diharapkan reski senantiasa bertambah dan bergerak maju. Diberikan reski yang melimpah dan berkesinambungan. Sagu tahan terhadap penyakit, diharapkan keluarga diberikan kesehatan dan mampu menghadapi tantangan dalam hidup. Sagu memiliki jangka tumbuh dan hidup yang panjang antara 6-15 tahun.

Rumpun sagu ( $p u^{\prime} u$ ndawaro) mempunyai fungsi sosial yang sangat besar nilainya dalam ketentuan hukum adat Tolaki. Rumpun sagu berfungsi sebagai alat penebus denda atas pelanggaran seseorang terhadap norma-norma sosial dalam masyarakat adat Tolaki. Menurut sara (adat) etnik Tolaki, apabila 
seseorang melakukan penghinaan terhadap seseorang baik dalam bentuk ucapan atau perkataan maupun berbuatan. Akan dikenakan peohala yaitu membayar denda dengan tebusan 1 (satu) rumpun sagu dalam bahasa Tolaki disebut aso rapu tawaro. Sagu juga berfungsi sebagai mahar dalam perkawinan perapua Tolaki yang disebut puu somba. Merupakan tradisi dalam adat suku Tolaki, bahwa apabila seorang melamar seorang gadis (mondeo pesuko) pihak pria membayar mahar 88 real uang tunai sebagai popolo. Seperangkat barang sebagai somba yang terdiri dari: 1 pis kain kaci sebagai ulu somba (pokok), 1 ekor kerbau adat (kiniku sara), 1 buah gong atau gumbang, 1 untai eno sara (kalung adat) berupa kalung emas, 1 rumpun sagu (aso rapu tawaro). Benda adat tersebut diatas muklat harus dipenuhi dan ditunaikan, karena kondisi sekarang dapat diganti dengan uang (okupa/odoi) dengan syarat senilai dengan benda tersebut.(Mekuo, 1986: 32, 45).

Sagu bermakna kesucian hal ini terdapat ungkapan ate pute penao moroha (hati suci yang ikhlas). Sagu memiliki duri perui yang tajam dibagian batang, daun (tawano), tangkai (tangge). Melihat pohon sagu merupakan tumbuhan yang kurang bersahabat, akan tetapi setelah diolah memiliki manfaat yang sangat berguna. Menurut orang Tolaki seperti itulah seharusnya manusia dalam melaksanakan aktivitasnya dapat berguna.

\section{Sagu dan Konsep Kepercayaan Tolaki}

Orang Tolaki percaya pada tandatanda alam. Dalam aktivitas pengolahan sagu selalu berpedoman pada kebiasaan orang tua menyangkut tanda-tanda alam. Jika padi menurut kepercayaan Tolaki memiliki roh yang disebut sanggoleo mbae (dewi sri). (Tarimana, 1993). Begitupun sagu menurut kepercayaan Tolaki memiliki roh (sanggoleo ndawaro). Karena itu sagu harus diperlakukan dengan baik. Hal ini terlihat apabila akan melaksanakan penebangan pohon sagu. Apabila dalam perjalanan ke lokasi untuk meramu sagu kemudian salah seekor binatang (babi obeke, tupai, kukus, ohada monyet) menyeberang pertanda tidak akan ada hasilnya. Kondisi tersebut dalam konsep kepercayaan orang Tolaki disebut mosa'a osui. Sehingga biasanya penebangan tidak dilakukan atau ditunda. Selain itu diperhatikan waktu yang baik untuk menebang, pada saat mehau-hau diharapkan bulan tersebut hasil panen akan melimpah. Jika pada saat sumandu proses pengambilan tepung sagu dari penampungan dan memasukan di dalam wadah sanggobi atau karung pengemasan aci sagu, orang yang melakukan sumandu tidak boleh mengisap rokok (moombi), bersuara atau berbicara (mebitara), karena akan terdengar oleh mahluk halus (wali kebo) yaitu jin yang dalam kepercayaan orang Tolaki pekerjaannya mencuri dari manusia, sehingga dikhwatirkan hasilnya akan berkurang. (Wawancara, Suparman, Lalobi, Bakuti, dan Sumi, 12 Oktober 2013). Dalam melakukan pemanenan seorang yang bertugas mengangkat aci sagu kedalam basung atau wadah penyimpanan terlebih dahulu membaca mantra yang disebut o'doa mombosuka (doa yang mengusir roh jahat pengganggu).

\section{Sagu dan Ekonomi Orang Tolaki}

Mengapa sagu sangat penting bila dibandingkan dengan tanaman lain, dan yang diperlukan untuk menghasilkan pati dari sagu lebih murah. Dapat meningkatkan pendapatan petani di pedesaan karena processing pati dapat 
dilakukan dalam skala rumah tangga. Produk turunannya berpotensi menciptakan lapangan kerja (seperti: daunnya dapat dijadikan atap, patinya dapat dijadikan kue dan makanan kecil, dapat dibuat cendera mata dan ulatnya dapat dimakan untuk menambah protein (Bintoro, 20013: 3). Sagu merupakan tanaman yang perlu dikembangkan untuk mengatasi masalah kekurangan bahan pangan karena dapat digunakan sebagai pangan cadangan, menghasilkan pati dalam jumlah banyak, apabila dipelihara secara baik. Produktivitasnya dapat mencapai 20-40 ton pati kering/ha/tahun. Sagu sebagai sumber kehidupan bagi masyarakat Tolaki. Menanam sagu adalah merupakan bagian dari sistem pertanian orang Tolaki. Sagu adalah termasuk makanan pokok penduduk di pedesaan di samping beras. Dengan demikian dapat dikatakan pohon sagu adalah sumber kehidupan bagi orang Tolaki.

Ungkapan tepohiu lalo epe, areal rumpun sagu yang luas, simbol ekonomi yang matang, ukuran kekayaan orang Tolaki masa lalu adalah berapa pohon dan luas ukuran areal tanaman sagu yang dimiliki. Dihitung berapa jumlah puu (pohon), tobu (areal), opio ndobu puu ndawaromu?, berapa luas areal tanaman sagumu?, pertanyaan ini sering terlontar kepada masyarakat Tolaki untuk mengukur kematangan ekonomi. Dari segi ekonomi, dalam usaha memenuhi kebutuhannya orang Tolaki menjadikan sagu sebagai makanan khasnya. Potensi ekonomi ini membuat munculnya usaha penjual sagu (paoli ndawaro), pedagang perantara sagu (papalele tawaro) atau penjual perantara tepung sagu. Di beberapa daerah terdapat pengusaha sagu salah satu keberhasilannya yaitu memiliki rumah mewah, memiliki mobil, menyekolahkan anak ke perguruan tinggi, dan berbagai kebutuhan hidup dapat terpenuhi. Mengolah sagu oleh sebagian masyarakat pedesaan merupakan mata pencaharian sampingan apabila setelah selesai panen yang dilanjutkan dengan musim kemarau yang panjang, maka banyak areal persawahan mengalami kekeringan terutama jenis sawa tadah hujan sehingga sawah tersebut tidak bisa diolah.

Peranan modal dalam usaha sekaligus pengembangan usaha memegang peranan penting, keberhasilan usaha ditentukan oleh tingkat kepemilikan modal. Semakin besar modal yang dimiliki maka semakin besar kemampuan seseorang untuk mengembangkan usahanya. Modal dapat berbentuk uang atau sarana untuk menunjang produksi. Mengolah sagu merupakan usaha yang tidak membutuhkan modal yang banyak dan untuk mendapatkan hasilnya juga sangat cepat berkisar antara 3-5 hari, pekerjaan ini dapat dilaksanakan satu atau dua orang dan cara berkelompok tergantung banyaknya pohon sagu yang akan diolah. Dalam proses pengolahan sagu secara tradisional mulai awal hingga akhir biaya yang digunakan tidak terlalu besar jika dibandingkan dengan jenis pekerjaan lain.

Hasil produksi sagu kemudian dijual dipasar atau pembeli pedagang perantara istilah lokal papalele. Harga sagu bervariasi, setiap volume berbeda harga jualnya, misalnya satu basung (aso basu), satu karung (aso karu), satu karung terigu (aso karu tarigu), sagu karung nilon kecil. Di pasar modern maupun tradisional di Kota Kendari, Unaaha, Kolaka, maupun di pedalaman pedesaan Kolaka berjejer penjual sagu dengan barbagai macam takaran. Penjual sagu dilakukan oleh laki-laki, tetapi mayoritas penjual sagu eceran di pasar adalah perempuan (more ndolaki).

Harga sagu setiap tahun semakin meningkat hal ini disebabkan oleh 
produksi pengolahan sagu yang terbatas. Sementara permintaan akan tepung sagu sebagai bahan makanan sinonggi terus meningkat. Sebab yang meminati mengkomsumsi sinonggi tidak hanya terbatas pada orang Tolaki bahkan diluar etnis Tolaki. Perkiraan hasil produksi sagu yang paling mendekati kenyataan pada kondisi liar dengan produksi 40-60 batang/ha/ tahun dengan jumlah empulur 1 ton/ batang, dengan kandungan aci sagu 18,5 persen, dapat diperkirakan hasil per hektar per tahun adalah 7-11 ton aci sagu kering. Secara teoritis, dari satu batang pohon sagu dapat dihasilkan 100 $-600 \mathrm{~kg}$ aci sagu kering. Rendemen total untuk pengolahan yang ideal adalah 15 persen. Dewasa ini petani sagu menjual pohon sagu berkisar antara Rp. 100.000,hingga Rp. 150.000,- perpohon. Selian itu hasil olahan petani menjual tepung hasil permentasi dengan cara eceran di pasar tradisional antara Rp.25.000,hingga Rp. 45.000,- perpaket.

Ada beberapa penyebab masyarakat Tolaki mengolah sagu yaitu: 1). Sagu merupakan makanan pokok sebagian masyarakat Tolaki selain beras, 2). Merupakan matapencaharian yang turun-temurun (tradisi), 3). Sumber daya dan potensi lahan yang memadai sangat menunjang usaha tersebut, 4). Mengolah sagu tidak membutuhkan modal banyak, dan 5). Kebutuhan ekonomi yang mendesak merupakan pilihan utama.

Munculnya aneka warung makan yang menyajikan makanan kuliner khas daerah Tolaki dengan menu sinonggi. Disebabkan makanan tersebut laris manis dan menjadi makanan favorit orang kaya. Bahkan ada warung yang tidak segan menulis warung sinonggi. Suatu kemajuan pada masa lalu mereka masih malu meokohanu untuk menjual sinonggi karena dianggap kuno atau tradisional.

\section{SIMPULAN}

Sagu sebagai identitas masyarakat Tolaki. Pohon sagu memiliki sejuta nilai bagi kehidupan orang Tolaki, dan memiliki kedudukan yang sangat vital. Hal ini disebabkan oleh beberapa hal yaitu: Sagu sangat penting bagi kehidupan orang Tolaki, karena pertama, pada masa lalu sebagai harta warisan (hapo-hapo tiari) simbol ekonomi, simbol kesejahteran, kedua, simbol adat sebagai seserahan, ketiga, sebagai makanan pokok, keempat sagu terkait dengan falsafah hidup Tolaki, kelima, berkenaan bahan baku peralatan, keenam, berkaitan dengan pola ekologi, tumbuhan dan akar sagu menahan erosi, dan banjir serta tanah longsor karena sagu memiliki akar serabut. Sagu bagi masyarakat Tolaki memiliki nilai berkaitan dengan aspek kehidupan mereka diantara sebagai simbol adat, falsafah sebagai pandangan hidup, sebagai sumber kehidupan fungsi ekonomi, fungsi ekologi, makanan pokok, dan memiliki fungsi sebagai sumber bahan baku dalam membuat alat tradisional bagi kehidupan Tolaki.

\section{DAFTAR PUSTAKA}

Anonim, 2013. Kebijakan Pengembangan Agribisnis dan Agroindustri Sagu di Kabupaten Kolaka Timur. Disampaikan pada Seminar Nasional Pengembangan Agribisnis/Agroindustri Sagu dan rapat Koordinasi Nasional (Rakornas) Himpunan Mahasiswa Pascasarjana Se-Indonesia.

Arsip BPAD Sulsel. Mengenai Laporan Kehutanan nomor: 814 Surat Camat Ranomeeto tanggal, 2 Desember 1978 perihal pembakaran dan pemusnahan tanaman sagu, nomor arsip $108 \mathrm{Kab}$. Kendari.

Ashur, Arsamid Al. 2007. Sistem Berburu dan Bertani Suku Toolaki. Unaaha. Tanpa terbit.

Bhurhanuddin, B, dkk. 1986/1987. Sistem 
Sagu (Tawaro) dan Kehidupan ... - Basrin Melamba

Ekonomi Tradisional: Sebagai Perwujudan Tanggapan Masyarakat Terhadap Lingkungannya di Sulawesi Tenggara. Kendari: Depdikbud.

Elbert, Johanes 1911. Sunda Expedition. Jerman.

Flach. 1997. Sago Palm. London: Periphus.

Fox J. James. 1996, Panen Lontar (Perubahan Ekologi Dalam Kehidupan Masyarakat Rote Dan Sawu ), Jakarta, Pustaka Sinar Harapan.

Fontjine, L. 1948. Adaat stelingen Onderafdeeling Kendari. Makassar: BAPD Sulawesi Selatan.

Goedhart, 1920."De inlandsche rechtsgemeennschappen in de Onderafdeeling Bonthain (1920), 171-174.

Jong, Cristian G. F. 2010. Nieuwe meester, Nieuwe goden: Geschiedenis van de Tolaki en Moronene twee volkeren in Zuidoost Celebes (Indonesie) van prehistorische tijden tot ca. 1950. IR-omschrijving: Europese Overzeese Expansie.

Koentjaraningrat, 1990. Pengantar Antropologi. Jakarta: Rineka Cipta.

Kruiyt, Alberts C. 1922. Een ander over Tolaki van Mekongga (Zuid Oost Celebes) Tijdschriff voor Indiche, Taal, Land en Volkenkunde Deel LXI. Alberrecht \& Co, Batavia.

Kruyt, Alberts C dan J. Kruyt, Verslag reisen in Onderafdeeling Kolaka, (KNAG XXXVIII, 1921.

Koodoh, Erens E. 2011. Hukum Adat Orang Tolaki. Yogyakarta: Teras.

Laporan perdagangan ekspor dan impor wilayah Kolaka dan Kendari. Kantor Arsip Daerah Sultra, 1946-1952).

Laporan Dinas Pertanian dan Holtikultura Provinsi Sultra, 2010.

Lakebo, Berthyn. 1986/1987. Pola Penguasaan Pemilikan dan penggunaan Tanah secara Tradisional daerah Sulawesi Tenggara. Kendari: Proyek Inventarisasi dan Dokumentasi Kebudayaan Daerah Depdikbud.

Mekuo, Djohan dkk. 1984/1985. Inventarisasi dan Dokumentasi: Aspek Makanan Dae- rah Sulawesi Tenggara. Kendari: Proyek Inventarisasi dan Dokumentasi Kebudayaan Daerah.

Marsali, Amri. 2009. Teori Struktural Fungsional. Majalah Antropologi: UI.

Melamba, Basrin. 2011. Kota Pelabuhan Kolaka Di Teluk Bone, 1906-1942. Bali: Pustaka Larasan.

Melamba, Basrin, dkk. 2013. Tolaki: Sejarah, Identitas, dan Kebudayaan. Yogyakarta: Lukita.

Purwanto, Hari. 2006. Manusia Kebudayaan dan Lingkungan Ekologis. Yogyakarta: Pustaka Pelajar.

Rembon, Fransiscus S. 2009. Studies on the Soil Physicochemical Properties of Sago Palm (Metroxylon Sagu Rottb). Growing Areas and Its Growth and Starch Productivity in Southeast Sulawesi, Indonesia. Japan: Kochi University.

Rianse, Usman dan Pasolon, Yulius B. Peran Perguruan Tingggi Dalam menunjang Pengembangan Sagu di Sulawesi Tenggara. Makalah disampaikan pada seminar Nasional Pengembangan Agribisnis/Agroindustri Sagu. Kendari, 26 November 2013.

Sairin, Sjafrin, Semedi, Puji dan Hudayana, Bambang. 1997. Pengantar Antropologi Ekonomi. Yogyakarta: Pustaka Pelajar.

Spradley, James. 2005. Pengantar Metode Etnografi. Jogjakarta: Tiara Wacana.

Su'ud, Muslimin. 2006. Osara: Hukum Adat Tolaki, 2006, Unaaha. LLPST.

Taagen, F.H.F. 1935. Memorie van Overgave van den Onderafdeeling Kendari. Leiden. Kode Arsip: KIT 1168.

Tarimana, Abdurrauf. 1993. Seri Etnografi: Kebudayaan Tolaki. Jakarta: Balai Pustaka.

Vosmaer, J.N. 1839. Korte Beschrijving van Zuid Oost Celebes Schrieland Van Celebes Het Bijzonder van Vosmaerbaai of van Kendari: met Berigten omtrentden Stam Der Badjo. Leiden: VBGKW.

Zlabbekoorn, 1937. Memorie van Onderafdeeling Kolaka. Koleksi: BPAD Sulsel. 